\title{
Formulation and Quality Evaluation of Enriched Balanced Weaning Food at Low Cost
}

\author{
BHIM PRASAD PULAMI ${ }^{*}$ and SURENDRA KATWAL
}

\author{
Tribhuvan University, Institute of Science and Technology, Central Campus of Technology, Dharan, Nepal
}

\begin{abstract}
Due to wide spread poverty, low income and non-availability of nutritious foods there are rampant of nutritional disorders such as protein energy malnutrition (PEM), anemia, vitamin-A deficiency, iodine deficiency disorder among preschool children in developing countries. Main purpose of the study is to formulate low cost supplementary weaning food from locally available raw materials. Based on the sensory evaluation, formula-I was preferred as a best sample ( $<0.05)$. Chemical analysis of formula-I had been performed and found to be 2.02\% moisture, $11.72 \%$ crude protein, 20.58\% crude fat, $3.11 \%$ total ash, $2.69 \%$ crude fiber, 59.88\% carbohydrate (by difference), $471 \mathrm{Kcal} / 100 \mathrm{~g}$ energy (calculated), $870.15 \mathrm{mg} / 100 \mathrm{~g}$ vitamin A (âcarotene; calculated), $11.86 \mathrm{mg} / 100 \mathrm{~g}$ iron, $275 \mathrm{mg} / 100 \mathrm{~g}$ calcium, $23.55 \mathrm{mg} / 100 \mathrm{~g}$ ascorbic acid, $35.6 \mu \mathrm{g} / 100 \mathrm{~g}$ iodine and $55 \%$ water absorbing capacity. The costing revealed the retail product price per $\mathrm{kg}$ as NRs. 71.20.
\end{abstract}

Keywords: Weaning food, Fortification, Amino acid score, Protein energy malnutrition, Micronutrient deficiency disorder

\section{Introduction}

Weaning is the transitional stage, when a young children's diet gradually changes from breast feeding alone to a supplementary diets based on what the family eats. Weaning begins when the child is introduced to foods other than breast milk (or a breast milk substitute) and is completed when the child is fully accustomed to the regular family diet. During weaning, the child should continued until to be breast-fed. Since breast milk is an important nutritional supplement to weaning foods (UNICEF, 1984).

Complimentary food formulation based on indigenous raw materials is must for all age-groups of all geographic regions especially for preschool children to overcome malnutrition in poor country like Nepal (K.C. and Kharel, 1990). Such foods should be nutritionally well balanced and should have a soft texture with very low fiber content (Chandrasekhar et. al., 1988). By introducing weaning food of good quality and quantity at right time and right proportion, the incidence of protein energy malnutrition (PEM) can be prevented to a large extent (Desikachar, 1982).

In market various nutritious weaning foods are available e.g. Cerelac, Farex, Bal-Ahar, Bal Amul, Nutri-pack etc. But they are unaffordable by low-income group of people. Therefore, there is an urgent need of reliable formulation and commercial production of low cost supplementary foods from locally available raw materials fortified with micronutrients e.g. vitamins and minerals. These protein rich foods can be used as a supplementary to the poor dietaries and also for the treatment and prevention of malnutrition in preschool children (Rao, 1961).

\footnotetext{
*Corresponding author, E-mail: bhimpulami@yahoo.com ${ }^{1}$ Present address: Regional Food Technology and Quality Control Office, DFTQC, Bhairawaha, Nepal
}

The weaning children, who are in a stage of rapid physical and mental growth, may require nutritionally balanced and hygienic foods. However, a large no of such children in Nepal are undernourished because of low income, lacking of awareness about nutrition, ignorance, unavailability of nutritious foods, food prejudices and social taboos of their parents. One of the main causes of under nutrition in infant is low income of people who cannot afford to buy high quality of expensive food such as meat, egg and supplementary other food in regular basis. In this context, the main objective of this study was to develop the weaning food formulae by utilizing locally available raw materials with fortified micronutrients at low cost for the infants of lower income group.

\section{Materials and Methods \\ Materials: Barley malt (collected from Brewery), Wheat, Rice, Soybean, Bengal-gram, Carrot, Fats (Ghee), Sugar and Salt these all are collected from Dharan bazaar. Ascorbic acid, Mineral salts, Anti-caking agent and antioxidant as reagent grade were purchased from chemical suppliers.}

Trial recipes: The four recipes for weaning formulas named as I, II, III and IV were formulated as given in Table 1.

Methods: The standard method of weaning foods preparation is given in Figure 1.

Sensory analysis: All the weaning food samples were subjected to sensory evaluation by scoring test method as per Ranganna, (1994). The evaluation was carried out by 15 semi-trained panelists including teachers, students and staff of Central Campus of Technology. Among them only 10 were selected for actual panel test on the basis of panelists' sensitivity on tests. The parameters and scores used for sensory test were; Taste -50, Flavor/smell -15, Appearance/ color -10 , Mouth feel (15), Overall quality -10 . Finally, the 
Table 1. Trial recipes of different weaning formulae

\begin{tabular}{|c|c|c|c|c|}
\hline Components* & I & II & III & IV \\
\hline Soybean (g) & 30 & 30 & - & - \\
\hline Bengal-gram (g) & - & - & 65 & 65 \\
\hline Wheat (g) & 68.78 & - & 30.73 & - \\
\hline Rice $(g)$ & - & 68.00 & - & 30.39 \\
\hline Malt (g) & 30 & 30 & 30 & 30 \\
\hline Carrot powder (g) & 7.4 & 7.4 & 7.4 & 7.4 \\
\hline Sugar (g) & 30 & 30 & 30 & 3 \\
\hline Iodised salt $35 \mathrm{ppm}(\mathrm{g})$ & 2 & 2 & 2 & 2 \\
\hline Ascorbic acid (g) & 0.05 & 0.05 & 0.05 & 0.05 \\
\hline $\mathrm{FeSO}_{4} \cdot 7 \mathrm{H}_{2} \mathrm{O}(\mathrm{mg})$ & 53.60 & 69.37 & 52.11 & 59.61 \\
\hline Fat $(\mathrm{g})$ & 31.72 & 32.48 & 34.77 & 35.10 \\
\hline
\end{tabular}

*BHA 0.04g and Calcium silicate 2.0g were mixed in each formula, each recipe is for $200 \mathrm{~g}$ product

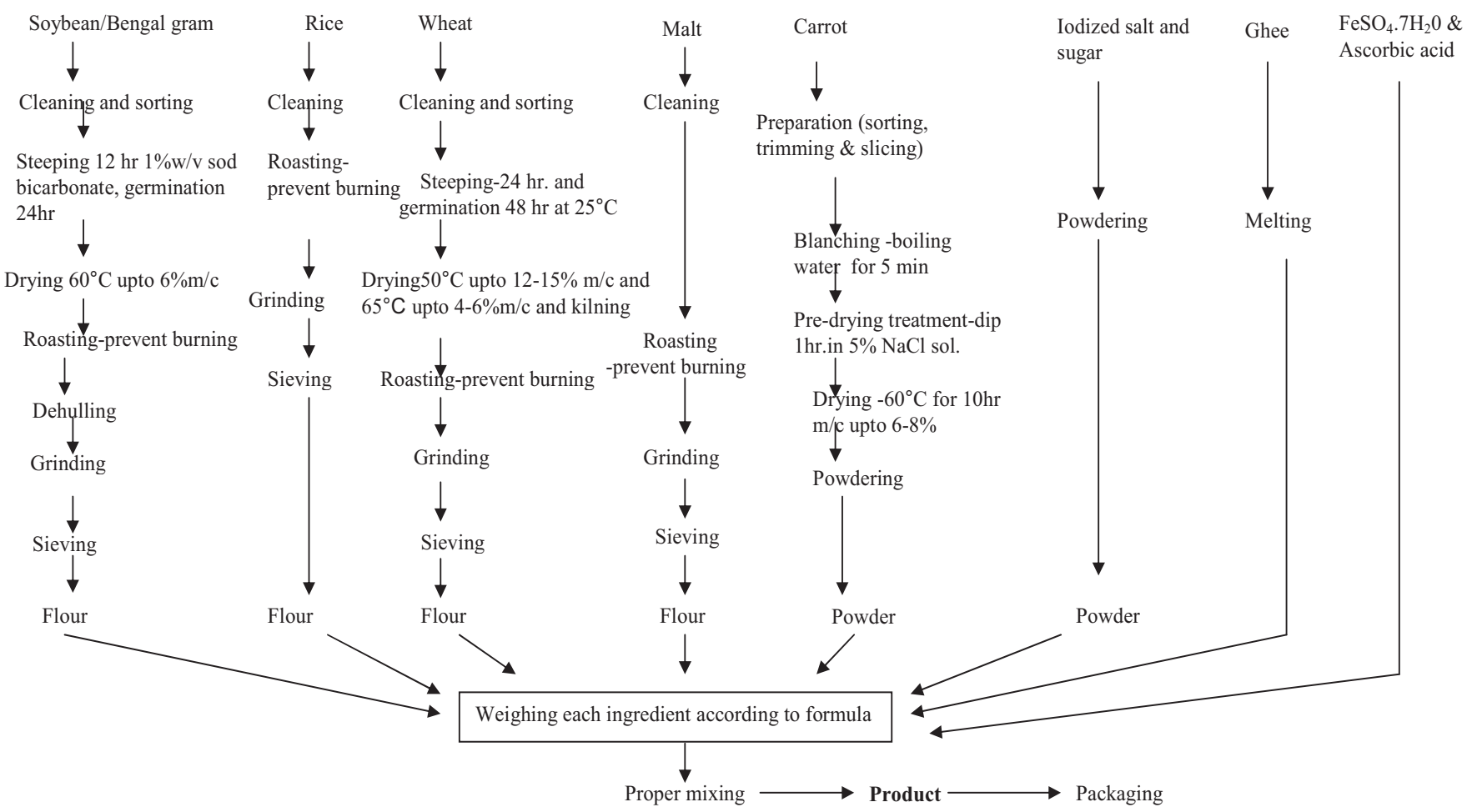

Figure 1. General flow -chart for the preparation of weaning food

total score for each sample was converted into ratio scale dividing by 10 .

Chemical analysis: The product was analyzed for moisture content, crude protein (Pearson, 1976), crude fat, total ash, crude fiber (Ranganna, 1994), total carbohydrate and energy value (Swaminathan, 1995), Iron, Ascorbic acid (Ranganna, 1994), calcium, â-carotene, and iodine (Pearson, 1976).

Amino acids calculation: The amino acids and their scores in different ingredients were calculated theoretically according to the method described by Swaminathan, (1995).

Statistical analysis: One way ANOVA was employed to test the test statistics for sensory attributes and Duncan Multiple Range Test (DMRT) was employed for mean comparison in case of sensory attributes were significantly different $(\mathrm{p}<0.05)$ (Ranganna, 1994).

\section{Results and Discussion}

All together four products namely; formula-I, II, II and IV were prepared and subjected to sensory evaluation. The sensory mean scores for all products are shown in Table 2 and mean difference analysis is given in Table 3.

From the mean difference analysis, formula -I obtained higher score. Similarly ANOVA test showed the formula-I was significantly different (pd"0.05) from II, III and IV formulae.

Chemical composition analyses: The chemical composition of highly preferred product (i.e. Formula- I) is shown in the Table 4. 
Table 2. Average mean of samples

\begin{tabular}{ll}
\hline Samples** & Mean* \\
\hline Formula- I (A) & $8.2 \mathrm{a}$ \\
Formula- II (B) & $7.4 \mathrm{~b}$ \\
Formula- III (C) & $7.13 \mathrm{~b}$ \\
Formula- IV (D) & $6.48 \mathrm{c}$ \\
\hline
\end{tabular}

*Mean score was converted into ratio scale by dividing 10

** Mean having the same letters $(\mathrm{a}, \mathrm{b}, \mathrm{c})$ in column indicate no significant difference $(\mathrm{p}>0.05)$

Table 3. Mean difference analysis

\begin{tabular}{lll}
\hline Mean comparison & Value & Tabulated Rp value at 5\% \\
\hline A-B & 0.89 & $>0.465$ \\
A-C & 1.07 & $>0.491$ \\
A-D & 1.72 & $>0.504$ \\
B-C & 0.27 & $<0.467$ \\
B-D & 0.92 & $>0.498$ \\
C-D & 0.65 & $>0.467$ \\
\hline * Test of significance $R p(5 \%)$ &
\end{tabular}

Table 4. Chemical composition of product-I

\begin{tabular}{ll}
\hline Composition & Mean values* \\
\hline Moisture $(\%)$ & 2.02 \\
Crude protein $(\%)$ & 11.72 \\
Crude fat $(\%)$ & 20.58 \\
Total ash $(\%)$ & 3.11 \\
Crude fiber $(\%)$ & 2.69 \\
Total carbohydrates (by difference) $(\%)$ & 59.88 \\
Energy (Kcal) (Calculated/100g) & 471.62 \\
Vitamin A $(\beta$-carotene $\mu \mathrm{g} / 100 \mathrm{~g})$ (calculated) & 870.15 \\
Iron $(\mathrm{mg} / 100 \mathrm{~g})$ & 11.86 \\
Calcium $(\mathrm{mg} / 100 \mathrm{~g})$ & 275.0 \\
Ascorbic acid $(\mathrm{mg} / 100 \mathrm{~g})$ & 23.55 \\
Iodine $(\mu \mathrm{g} / 100 \mathrm{~g})$ & 35.60 \\
Water absorbing capacity $(\%)$ & 55.0 \\
*Values are mean of triplicates and expressed in wet weight basis
\end{tabular}

The moisture content in formula-I (most preferred) was found to be $2.02 \%$, which seems enough to control microbial activity in product due to low moisture content that would increases the shelf-life of the product. Similarly, the formula-I contained $3.11 \%$ ash as well as mineral content as iron, iodine and calcium $11.86 \mathrm{mg} / 100 \mathrm{~g}, 35.60 \mu \mathrm{g} / 100 \mathrm{~g}, 275.0 \mathrm{mg} / 100 \mathrm{~g}$ respectively. The requirement of iron (7-10 $\mathrm{mg}$ to $12 \mathrm{mg}$ for 6 to 12 months infant) could be fulfilled the requirement from $100 \mathrm{~g}$ product. Additionally, the requirement of calcium $(500 \mathrm{mg}$ per day for 6-12 months infant) could be fulfilled by consuming $200 \mathrm{~g}$ of the product, while the requirement of iodine $(45 \mu \mathrm{g} /$ day for 6-12 months infant) could be fulfilled from $126.4 \mathrm{~g}$ of product.

Since, the dietary fibers play a vital role in human nutrition its incorporation in the form of whole meal flour, pectin, fruit fiber and high fiber carbohydrate diet can control the blood glucose levels for diabetes. According to Statland (1992), diet containing controlled amount of fiber i.e. less than or equal to $40 \mathrm{~g}$ of fiber daily that includes fruits and vegetables will prevent up to $35 \%$ of cancer risk. The analysis result showed $2.69 \%$ of fiber was found in product, which might be due to the extraction of whole meal flour from different ingredients.

According to Swaminathan (1995), the recommended amount of fat in the diet of infants in India and other developing countries should provide $40-50 \%$ of total calorie in diet. The result showed $20.58 / 100 \mathrm{~g}$ fat, which will provide $39.27 \%$ of total calorie.
The vitamin-A recommended by ICMR, (1989) is $1200 \mu \mathrm{g} /$ day â-carotene for a six month infant. From calculated data, âcarotene found to be $870 \mu \mathrm{g} / 100 \mathrm{~g}$ products. Thus $137.9 \mathrm{~g}$ of product will fulfill the child's daily need. Similarly, $50 \mathrm{mg}$ of ascorbic acid was incorporated in recipe but $47.1 \mathrm{mg}$ of vitamin$\mathrm{C}$ in $200 \mathrm{~g}$ product was found. Therefore, about $106.15 \mathrm{~g}$ of product will fulfill the daily requirement of six month infant (ICMR, 1989).

The energy value was found to be $943.24 \mathrm{Kcal}$ per $200 \mathrm{~g}$. This quantity of energy is sufficient for 6-12 months old infant comparing with requirements.

The products were formulated on the basis of protein, essential amino acids, vitamin A, Iron, and Iodine requirement for infants. The calculated amounts of amino acids found in products were higher than average minimal daily requirement with compared to average minimal daily amino acid requirements (Holt and Synderman, 1965) (Table 5).

Germination and malting of raw material could increase the digestibility of weaning foods, where various types of enzymes will be liberated and involved in changing protein, starch and other nutrients into simpler forms. In other hand, it will decrease the anti-nutritional factors containing in raw materials. Malting process could improve the flavor for the acceptability of such foods. Therefore, the reason might be the product prepared from germinated and malted soybeans and wheat was found to be significantly superior $(\mathrm{p}<0.05)$ to other formulae. 
Pulami \& Katwal : J. Food Sci. \& Technol. Nepal, 6 (118-121), 2010

Table 5. Calculated amount of amino acids and their scores

\begin{tabular}{lllll}
\hline $\begin{array}{l}\text { Essential } \\
\text { amino acid }\end{array}$ & $\begin{array}{l}\text { Product-I } \\
\text { (g/200g) }\end{array}$ & $\begin{array}{l}\text { Minimal daily amino acid } \\
\text { requirement } \\
\text { (g//kg) }\end{array}$ & $\begin{array}{l}\text { Amount required for 6-12 } \\
\text { infant } \\
\text { months infants (i.e., 8.6kg) } \\
\text { in } \mathbf{~}\end{array}$ & $\begin{array}{l}\text { Amino acid } \\
\text { score }\end{array}$ \\
\hline Lysine & 1.15 & 0.103 & 0.89 & 83.6 \\
Tryptophan & 0.32 & 0.022 & 0.2 & 130 \\
Leucine & 1.75 & 0.15 & 1.3 & 100 \\
Valine & 1.21 & 0.105 & 0.9 & 96 \\
Isoleucine & 1.18 & 0.119 & 1.02 & 117.5 \\
Threonine & 0.85 & 0.087 & 0.75 & 85 \\
Phenylalanine & 1.18 & 0.09 & 0.78 & 134.2 \\
Methionine & 0.38 & 0.045 & 0.38 & 72.2 \\
Histidine & 0.52 & 0.034 & 0.3 & N/A* \\
\hline *Not
\end{tabular}

According to the ICMR (1998) report, the recommended amount of complete protein for six month healthy child should be $14.19 \mathrm{~g} /$ day. From the result, the protein content of product was found to be $11.72 \mathrm{~g} / 100 \mathrm{~g}$ with $72.2 \%$ amino acid score. According to Swaminathan (1995), 20g/day protein with 70\% protein score is required for children. Therefore consuming $170.64 \mathrm{~g}$ of product could fulfill the child's daily need of complete protein. With growing age the food consumption capacity of child will be increased (Cameron and Hofvander, 1983).

Sensory evaluation: Considering the most effective cost factors in manufacturing such as raw materials, electricity, labor, packaging material and overhead costs the retail price for the product was calculated. However, this cost may vary with time and season. Therefore, the contingency cost (10\%) and $10 \%$ profit margins were included. It was found that such type of product could be prepared at about NRs.71.20/kg., which is much cheaper than any weaning foods available in market.

\section{Conclusion}

Low cost (NRs $71 / \mathrm{kg}$ ) weaning food could be manufactured in a commercial scale by utilizing locally available raw materials like as soybean, Bengal-gram, wheat, rice and malt enriched with micronutrients sources such as dried carrot powder for vitamin-A, sugar and salt for taste and flavor respectively. From the sensory evaluation, formula-I was found to be the best product. The product obtained from germinated soybean and malted wheat was found to be significantly superior to other formula. The calculated amount of essential amino acids in product-I (in $200 \mathrm{~g}$ basis) was found to be higher than the minimal daily requirement of amino acid for infant.

Since, the formulated weaning food was rich in micronutrients with good palatability and cheaper could be useful as nutrient supplementary to prevent protein calorie malnutrition as well as micronutrients deficiency disorders in developing countries like Nepal.

\section{References}

Cameron M. and Hofvander Y. (1984). How to develop recipe for weaning foods on manual: feeding infants and young children. Oxford University Press.
Chandrasekhar U, Bhooma N. and Reddy S. (1988). Evolution of a malted weaning food based on low cost locally available foods. Indian J. Nutr. and Dietetic., 25:37-43.

Desikachar H. S. R. (1982). Technology options for formulating weaning food for the economically weaker segments of population in developing countries, J. Food Nutri. Bulletin, 4:57-59.

Swaminathan M. (1993). Essentials of Food and Nutrition vol-I, Food and Nutrition Board, Nutritional Research Council, USA, In: FNB and NRC, (1980), pp 523.

Holt and Synderman (1965). Average minimal daily amino acids requirements for infant. In: Essential of food and nutrition, Swaminathan, Vol.-I, 1995, pp 201.

ICMR (1989). Recommended dietary allowances for infants. In: Food and Nutrition Vol.-II, appendix-I, M. Swaminathan, (1993), Bappco, Banglore.

Pearson D. (1976). The chemical analysis of food $\left(7^{\text {th }}\right.$ edn). Churchill Livingstone.

Rangana S. (1994). Handbook of analysis and quality control for fruits and vegetable products. 2nd (Edn), Tata Mc Grass Hill publishing company limited, New Delhi.

Rao P. (1961). Treatment of protein malnutrition in children with a vegetable protein food. In: symposium on protein (August 1961). CFTRI, Mysore (ed.) K. A. Rorula at the Wesley press Mysore.

Swaminathan M. (1974). Essential of food and nutrition. $1^{\text {st }}$ edn, Vol. II, printing and publishing house press.

Swaminathan M. (1993). An advance text book of food and nutrition. Vol. II, $2^{\text {nd }}$ edn, Bappco printing press.

Swaminathan M. (1995). An advance text book of food and nutrition. Vol. I, 3rd edn, Bappco printing press.

Statland B. E. (1992). Nutrition and Cancer. Clinical Chemistry, (Abstr.) 38 (8B Pt2), 1987-94.

UNICEF (1998). The report on the state of world's children. In: The Rising Nepal, Kathmandu, Dec.17, 1997, pp 1-8.

UNICEF (1984). Program activities for improving weaning practices (Information for action issue paper), pp 5-7 